\title{
EL CADIAZGO EN GRANADA BAJO LOS ALMORÁVIDES: ENFRENTAMIENTO Y NEGOCIACIÓN
}

\author{
RACHID EL HOUR
}

\author{
Universidad de Salamanca
}

\begin{abstract}
Este artículo estudia dos aspectos primordiales del cadiazgo de la ciudad de Granada bajo los almorávides. Por un lado, expone la lista de cadíes de Granada basándose en los datos proporcionados por las fuentes biográficas andalusíes. Por el otro, analiza los mecanismos de la relación entre el poder político almorávide y la élite local granadina, relación que se caracterizó, en gran medida, por la negociación y el enfrentamiento. El cadiazgo de Granada fue gestionado por varias familias andalusíes, granadinas y no granadinas, y no por voluntad propia de los granadinos, sino por imposición de las autoridades almorávides. También, encontramos miembros de familias magrebíes ocupando el cadiazgo en mayor número del que se produce al mismo tiempo en otras ciudades andalusíes - no se incluye a Algeciras por razones ligadas especialmente al estatuto de la ciudad-. Con esto, las autoridades almorávides querían evitar el monopolio de las funciones judiciales por parte de la élite local, y con ello ejercer mayor control sobre la ciudad, sobre todo teniendo en cuenta que era la capital andalusí.
\end{abstract}

Palabras clave: Granada; cadiazgo; Almorávides; élites locales; negociación; enfrentamiento
This article studies two outstanding aspects of the $q \bar{a} d \bar{l}$ ship of the city of Granada under the Almoravids. First of all, it lays out the list of $q \bar{a} d \bar{l} \bar{s}$ in Granada based on the data provided by Andalusi biographical sources. Secondly, it analyses the mechanisms of the relationship between Almoravid political power and the local elites of Granada - a relationship which was largely characterised by both negotiation and confrontation. The qādiship of Granada was managed by several Andalusi families, from Granada and outside it. Such management was imposed by the Almoravid authorities rather than by the Granadans themselves. We also find members of Maghrebi families occupying the qādiship in higher numbers then in other Andalusí towns of the some period city (this excludes Algeciras for reasons linked especially to the city's status). In this way, the Almoravids authorities sought to avoid the monopoly of the judicial functions held by local elites and thereby exercise greater control over the city, which was of particularly great importance given that it was the Andalusi capital.

Keywords: Granada; qāọ̄iship; Almoravids; local elites; negotiation; confrontation

Durante la época de taifas, al-Ándalus estuvo dominado por élites de árabes, beréberes y eslavos, que se hicieron con el poder en sus respectivas ciudades, proclamándose independientes. La ciudad de Granada cayó en manos de los ziríes (beréberes), que controlaron la ciudad hasta que fueron derrocados por los Almorávides ya a finales del siglo XI ${ }^{1}$.

${ }^{1}$ Exactamente el 15 de raŷab de 483/13 de septiembre de 1090. Los almorávides desterraron y encarcelaron al rey de Granada 'Abd Allāh en Agmāt, donde murió. 
En época almorávide, la ciudad de Granada destacó por su papel como capital político-militar de al-Ándalus. También lo hizo por haber sido un centro urbano de gran importancia y lugar de residencia y establecimiento de una élite urbana social y económicamente importante $^{2}$, cuyos intereses se enfrentaban, de vez en cuando, con los de otras élites norteafricanas (apoyadas por las autoridades políticas almorávides), sobre todo por el control del cadiazgo de la ciudad.

En este artículo, intentaré esencialmente abordar dos aspectos. Por un lado, estudiar las características del cadiazgo de Granada, y por el otro, analizar la relación del poder local y del poder político almorávide a través del cadiazgo establecido en la ciudad.

\section{Cadiazgo de Granada}

Mis recientes trabajos ${ }^{3}$ sobre el cadiazgo de varias localidades andalusíes me han llevado a las siguientes conclusiones. El ejercicio de los cargos judiciales dependía, en cierto modo, del poder local, aunque hay que subrayar que las autoridades almorávides siempre intentaban salir de esta norma con el fin de conseguir el mayor control posible de la actividad judicial andalusí. Este predominio de los poderes locales sobre los judiciales y la naturaleza de la política emprendida por las autoridades políticas y militares almorávides se pueden apreciar en localidades como Córdoba, Sevilla, Almería y en el Levante

${ }^{2}$ Hay varios trabajos que han tratado sobre las élites locales granadinas. Véase en particular Fórneas, J. M., "Los Banū 'Atịyya de Granada", MEAH XXV (1976), 69-80; XXVI (1977), 27-60 y XXVII-XXVIII (1978-79), 65-77; Elencos biobibliográficos arábigoandaluces. Estudio especial de la fahrasa de Ibn 'Atiyya al-Garnāți (481-541/ 1088-1147), Facultad de Filosofía y Letras, Madrid, 1971; Fierro, M., "The qãd̆i as ruler", en Saber religioso y poder político en el Islam, Madrid, 1994, 71-116; El Hour, R., "La transición entre las épocas almorávide y almohade vista a través de las familias de ulemas", en M. Fierro-M. L. Ávila (eds.), Estudios Onomástico-Biográficos de al-Andalus (EOBA) IX (1999), vol. I, 261-305; Serrano, D., "Los Banū 'Iyāḍ, de la caída del Imperio Almorávid a la instauración de la dinastía nazarí", en M. Fierro-M. L. Ávila (eds.), IX (1999), vol. I, 352-406; Lucini, M., "Los Banū Samaŷūn: una familia de cadíes", EOBA V (1992), 171-198.

3 Véase El Hour, R., "Córdoba frente a los almorávides: familias de cadíes y poder local en al-Andalus", RIEEI XXIX (1997), 182-210; «Sevilla en época almorávide: sede de una importante administración judicial», RIEEI XXXI (1999), 33-50; «Almería almorávide: sede de una oposición política y de un importante poder judicial», RIEEI XXXII (2000), 99-118; «El Levante de al-Andalus en época almorávide: jueces y élites locales», Al-Andalus-Magreb X (2003), 53-89.

Al-Qanțara (AQ) XXVII 1, enero-junio 2006, pp. 5-23 ISSN 0211-3589 
(Murcia, Valencia y sus respectivas dependencias judiciales). ¿Cómo se ha reflejado esta política en el cadiazgo de Granada?

En primer lugar, voy a limitarme a exponer los datos que proporcionan las fuentes biográficas acerca de los cadíes de Granada, y luego procederé a su análisis. De estas fuentes se obtiene la siguiente lista de cadíes:

1. Abū l-Aṣbag 'İsà b. Sahl ${ }^{4}$. Natural de Jaén, de los Barâŷila. Fue jurisconsulto en Córdoba por una corta temporada y secretario de su gobernador Ibn Ŷarīs; luego secretario del cadí Abū Zayd b. al-Ḥaššā' de Toledo, cargo que abandonó por haber sido castigado a causa de un asunto que se le reprochó (li-amr naqama-hu 'alay-hi). También fue secretario del cadí Abū Bakr b. Manzūir de Córdoba; después cadí de Tánger y Mequínez en época bargawātí, y finalmente cadí de Granada por una temporada hasta la llegada de los almorávides. Respecto a este último cargo no se sabe por qué V. Lagardère habla de qā dị quḍāt de Granada en la época almorávide, ya que ninguna de las fuentes que he manejado utiliza este término para designar a los cadíes de Granada. Además llama a Ibn Sahl qāại l-ŷamà 'a de Granada. Las fuentes biobibliografías más importantes de la época no hablan de ningún qãḍī al-yamā 'a de Granada. En al-Ándalus el término qaḍi al-ŷmā'a sólo lo llevaba el cadí de Córdoba, y en el Magreb, el de Marrakech, junto con otros términos, como qāḍi l-maḥalla, qāại l-quḍāt y qāộ̀ l-ḥadra ${ }^{5}$.

Ibn al-Sayrafī ${ }^{6}$ dice que Ibn Sahl fue destituido por Yūsuf $b$. Tāšufin por ser muy duro en sus sentencias (rufi'a ilay-hi šiddatu-hu $f i-l-q a d \bar{a}^{\prime} f a-s a r a f a-h u$ ). Parece que su destitución no se debió a la naturaleza de sus sentencias, sino más bien a otras razones relacionadas tanto con la nueva política que querían implantar los almorávides en al-Ándalus respecto a su relación con el poder local andalusí, como con la lealtad del cadí de Granada. No cabe duda de que los almorávides, recién llegados a al-Ándalus, tenían planes específicos para la ciudad de Granada, hecho que nos explica, como veremos más ade-

${ }^{4}$ Ibn Baškuwāl, Kitāb al-Sila, ed. 'I. al-'Attār, 942; 'Iyād, Tartīb al-madārik, t. VIII/182-183; Ibn Farḥūn, al-Dībāŷy al-mudhab, II/70-72; al-Bunnāhī, al-Marqaba al- 'ulyā, 96-97; al-Dabbī, Bugyat al-multamis, 1148; Majlūf, Saŷarat al-nūr al-zakiyya, 122.

5 Cf. Lagardère, V., "La haute judicature à l'époque almoravide en al-Andalus", Al-Qantara VII (1986), 135-228, 176.

${ }^{6}$ Citado por Ibn Farhūu, al-Dībāŷy al-mudhab, II, 172.

Al-Qanțara (AQ) XXVII 1, enero-junio 2006, pp. 5-23 ISSN 0211-3589 
lante, la naturaleza de los nombramientos judiciales para el cadiazgo de la ciudad de Granada, sobre todo a la hora de compararlos con los realizados en otras ciudades, como pueden ser Córdoba y Valencia.

2. Abū l-Hasan 'Abd al-Raḥmān b. Muhammad b. Sayyid Abī-hi ${ }^{7}$. Era natural de Cabra según Ibn al-Abbār, y de Córdoba según Ibn al-Zubayr. Fue nombrado miembro de la šūrà wa-ahkām al-sūq - funciones que parece haber ejercido al mismo tiempo- de Córdoba por el cadí Abū Bakr 'Ubayd Allāh b. Muhammad b. Adham; luego cadí de Granada por el emir Yūsuf b. Tāšufīn en 485/1092-1093 ó 486/1093-1094. El gobernador de Granada, Yahyà, lo destituyó de su cargo en dū l-qa'da de 489/noviembre de 1096 y lo exilió en Córdoba, donde falleció.

3. Abū Muhammad 'Abd Allāh b. 'Alī b. 'Abd al-Malik b. Ibrāhīm, al-Hilālī al-Garnātīi, Ibn Samaŷūn al-Lawātī ${ }^{8}$. Natural de Tánger ${ }^{9}$. Fue nombrado cadí de Algeciras por el emir Yūsuf b. Tāšufĩn; luego lo nombró cadí de Granada en 490/1096-1097 y allí permaneció hasta el mes de rabī‘ II 508/septiembre de 1114, después de haber participado en la Batalla de Talavera en 503/1109-1110. Ibn Samaŷūn fue destituido, al parecer, a causa de un conflicto con los alfaquíes de Granada, sobre todo con miembros de la familia de los Banū 'Ațiyya. A consecuencia de este conflicto, Abū Bakr Gālib b. 'Ațiyya ${ }^{10}$ fue deportado al Sūs, y el emir de Córdoba Mazdalī humilló a 'Abd al-Haqq (hijo de Gālib b. 'Ațiyya) y lo encarceló, aunque Ibn 'Ayyād ${ }^{11}$ dice que fue deportado junto con su padre.

4. Abū Bakr Muhammad b. Aḥmad b. Jalaf b. 'Abd al-Malik b. Gālib al-Gassānī, Ibn al-Qulay 'ī ${ }^{12}$ (m. 510/1116). Fue nombrado cadí de Granada por acuerdo de los granadinos en 508/1114, cargo que ejerció hasta que murió el 1 de șafar de 510/15 de junio de 1116 .

7 Ibn al-Abbār, al-Takmila li-kitāb al-Sila, ed. F. Codera, 2 vols., 1565; Ibn al-Zubayr, Șilat al-șila, ed. 'A.S. al-Harrās y S. A'rāb, 295; Ibn al-Zubayr, Șilat al-șila, ed. E. Lévi-Provençal, 148

${ }^{8}$ Ibn al-Abbār, al-Takmila li-kitāb al-Sila, ed. 'I. al-Husaynī, 1955, p. 915 (n. ${ }^{\circ} 2138$ ) y p. 819 (n. ${ }^{\circ}$ 1994); Ibn al-Zubayr, Silat al-sila, ed. 'A.S. al-Harrās y S. A'rāb, 255; al-Marrākušī, al-Dayl wa-l-takmila, IV (2), ed. I. 'Abbās, Beirut, s. a., 192.

9 Las fuentes ofrecen distintas fechas de nacimiento; Ibn al-Abbār dice que nació en 444/1052-1053, pero además informa de que 'Abd al-Haqq b. Būnuh, en su Barnāmây, dice que nació a finales de 447/1055-1056 (ésta es la misma fecha que cita Ibn al-Zubayr).

${ }^{10}$ Majlūf, šaŷarat al-nūr 374; al-Dabbī, Bugyat al-multamis, 1885.

11 Creo que se trata de Abū l-Hasan Yūsuf b. 'Abd Allāh b. Sa'īid, Ibn 'Ayyād, alfaquí, sabio polifacético y tradicionista, murió en 575/1179-1180. Cf. Majlūf, Šayarat al-nūr, 465 .

${ }^{12}$ Ibn al-Abbār, al-Takmila, ed. 'I. al-Husaynī, 1166.

Al-Qanțara (AQ) XXVII 1, enero-junio 2006, pp. 5-23 ISSN 0211-3589 
5. Abū Sa'īd Jallūf b. Jalaf Allāh al-Ṣanhāŷī (m. 515/1121-2) ${ }^{13}$. Natural de Fez, fue nombrado cadí de Granada tras la muerte de Abū Bakr al-Qulay‘ī en 510/1116-1117 y permaneció en su cargo hasta 515/1121-1122; luego lo nombraron cadí de Fez y finalmente qāọi l-y̆amā'a de Marrakech hasta su muerte.

6. Abū 'Abd Allāh Muḥammad b. 'Abd Allāh ('Ubayd Allāh) b. Husayn b. 'Īsà b. Husayn al-Kalbī ${ }^{14}$, Ibn Hassūn ${ }^{15}$. Sucedió a su padre en el cadiazgo de Málaga; luego lo nombraron cadí de Granada el 3 de dū l-qa'da de 515/13 de enero de 1122, y permaneció en su cargo hasta 519/1125-1126.

7. Abū Muhammad 'Abd al-Mun'im b. Marwān b. 'Abd al-Malik b. Samaŷūn b. Ibrāhīm b. 'Īsà b. Șālih al-Hilālī (m. 524/1130) ${ }^{16}$. Natural de Tánger, aunque creció en Granada. Fue nombrado cadí de Granada; además sucedió a Ibn Aḍ̣à en el cadizago de Almería en 517/1123-1124 ${ }^{17}$. Ibn al-Abbār informa de que se le nombró cadí de Sevilla tras la destitución de Abū Marwān al-Bāŷī ${ }^{18}$. Debió de ocupar el cargo antes de 524/1130.

8. Abū 1-Qāsim Aḥmad b. Muhammad b. 'Umar b. Yūsuf b. Idrīs b. 'Abd Allāh, al-Tamìmīi ${ }^{19}$, Ibn Ward ${ }^{20}$ (m. 540/1146). Natural de Almería. Ibn 'Ayyād dice que ejerció el cargo de cadí de Córdoba, pero Ibn al-Abbār lo desmiente y dice que fue cadí de Granada y luego cadí en Sevilla. Además fue muftí en Córdoba después de haber dejado el cargo de cadí. Ibn Baškuwāl dice que desempeñó el cargo en varias

13 Ibn al-Qāḍī, Ŷadwat al-iqtibās, vol. I/152, p. 193; Ibn al-Abbār, al-Takmila, ed. 'I. al-Husaynī, 850.

14 Sobre esta familia véase Fórneas, J. M., "Los Banū 'Ațiyya y los Banū Hassūn al-Kalbī”, R. El Hour, "La transición" y M. Fierro, "The qādì as ruler".

15 Al-Marrākušī, al-Dֵayl, t. VI, ed. I. 'Abbās, Beirut, 1973 (2 partes), 870; Ibn al-Abbār, al-Takmila, ed. 'I. al-Ḥusaynī, 1196; al-Ḍabbī, Bugya, 187.

${ }^{16}$ Ibn al-Abbār, al-Takmila, ed. Codera, 1816; al-Marrākušī, al-Dayl, ed. M. Bencherifa, VIII/2, 545; Ibn al-Zubayr, Silatal-șila, ed. Lévi-Povençal, 32.

17 Al-Humaydī recoge la carta del emir 'Alī b. Yūsuf b. Tāšufīn, donde habla de la mala reputación que tuvo este cadí, y que consiste en la destitución de este personaje. Véase al-Silafī, Ajbār wa-tarāŷim andalusiyya, ed. I. 'Abbās, Beirut, 1963, 78; Ibn Sa'īd, al-Mugrib fì hulà al-Magrib, ed. Š. Dayf, El Cairo, 1955, t. II/108; Ibn Jāqān, Qalā'id al- 'iqyān, 216.

18 También Ibn 'Iḍārī nos dice que ocupó el cargo de cadí de Sevilla después de la destitución de Abū Marwān al-Bāŷī. Véase al-Bayān al-mugrib, IV, 58.

19 Ibn Baškuwāl, Șila, ed. El Cairo, 177; Ibn al-Abbār, al-Mu '̂yam, 17, pp. 23-26; Ibn Farḥūn, al-Dỉbāŷ, I/185-186; al-Dabbī, Bugya, 363.

20 Véase El Hour, R., "Almería almorávide: sede de una oposición política y de un importante poder judicial», RIEEI XXXII (2000), 99-118.

Al-Qanțara (AQ) XXVII 1, enero-junio 2006, pp. 5-23 ISSN 0211-3589 
ciudades importantes (bi-gayr mawḍi ' min al-mudun al-kubrà). Debió de ocupar el cargo de cadí de Granada en 519/1125-1126 ${ }^{21}$.

9. Abū 'Imrān Mūsà b. 'Abd al-Rahmān b. Hammād al-Sanhāŷī 22 (m. 535/1141). Natural del Garb en el Norte de África. Fue cadí de Granada ${ }^{23}$ en dos ocasiones, la primera en šawwāl de 524/septiembre de 1130, y luego de Marrakech. Ibn Baškuwāl no menciona el cargo de cadí de Granada; en cambio Ibn al-Zubayr no menciona el cargo de cadí de Marrakech.

10. Abū Bakr 'Abd al-Raḥmān b. al-Ḥasan b. Qāsim b. Mušarrif b. Hāni', al-Lajmī (m. 539/1145) ${ }^{24}$. Debió de ocupar el cargo entre $525 / 1131$ y $529 / 1134-5$, ya que las fechas referentes al resto de los nombramientos están mejor documentadas. De todas formas, el período situado entre 524/1130-1 y 531/1137-8 es un poco confuso con respecto al cadiazgo de la ciudad. Esta «aparente» confusión podría deberse a la inestabilidad política del país, aunque hay que tener en cuenta que los escasos datos que nos proporcionan las fuentes árabes impiden ofrecer conclusiones definitivas al respecto.

11. Abū Hafṣ 'Umar b. Muhammad b. 'İsà b. Sulaymān al-Hamadānī al-Ilbīrī ${ }^{25}$ (m. alrededor de 530/1135-1136). Jurisconsulto, luego fue nombrado cadí de Granada. No se conocen las fechas de su cadiazgo, aunque se puede deducir que debió de ejercer el cargo antes de 530/1136-1137.

12. Abū 1-Qāsim Muḥammad b. Hišām b. Aḥmad b. Walīd al-Umawī, Ibn Abì Ŷamra ${ }^{26}$ (m. 530/1136-37). Natural de Murcia. Fue cadí de Granada, cargo que ejerció hasta su muerte, es decir que fue cadí hasta 530/1136-1137.

13. Abū l-Faḍl 'Iyāḍ b. Mūsà b. 'Iyāḍ b. Hārūn b. Mūsà b. 'Iyāẹ b. Muhammad b. 'Abd Allāh b. Mūsà b. 'Iyāḍ al-Yaḥ̣subīi 27

${ }^{21}$ Ibn 'Iḍārī, al dar las noticias de ese año, dice: «Cuando regresó de su expedición (se refiere al gobernador almorávide antes citado), aumentó el ta 'tīb (impuesto para construir las murallas en al-Ándalus) de la ciudad y se encargó de ello aquél en quien se convino por el cadí de la región, Abū l-Qāsim b. Ward...». Al-Bayān, 73, trad. 170.

${ }^{22}$ Al-Marrākušǐ, al-Dayl wa-l-takmila, VIII/2, 524; Ibn al-Zubayr, ed. 'A. Harrās y S. A'rāb, 57; Ibn Baškuwāl, ed. El Cairo, 1342; al-Ḍabbī, Bugya, 1330.

23 Al-Bunnāhī nos ofrece el acta de su nombramiento. Véase al-Marqaba al-'ulyā, 98. Dicha acta fue escrita a principios de ramaḍān de 524/agosto de 1130.

${ }^{24} \mathrm{Ibn}$ al-Abbār, al-Takmila, ed. Codera, 1590.

25 Ibn al-Abbār, al-Takmila, ed. Lévi-Provençal, 112.

26 Ibn Baškuwāl, Șila, ed. El Cairo, 1279.

27 Ibn Baškuwāl, Șila, ed. El Cairo, 975; 'Iyāẹ, al-Gunya, ed. M. Ŷarrār, Beirut, 
(m. 544/1149). Natural de Ceuta, fue jurisconsulto en esa ciudad cuando regresó de al-Ándalus en 508/1114, luego cadí de Ceuta desde șafar de 515/mayo de 1121 hasta 531/1136-1137, después cadí de Granada en 531/1136-1137 por una temporada corta, ya que, y por motivos desconocidos, lo destituyó Tašufīn b. 'Alī un año después, es decir, en 532/1137-1138; al final lo nombró Ibrāhīm b. Tāšufīn de nuevo cadí de Ceuta por un corta temporada en 539/1144-1145.

14. Abū 'Abd Allāh Muhammad b. 'Alī al-Azdī, Ibn al-Hāâŷy al-Afțas ${ }^{28}$ (m. 536/julio de 1142). Natural de Jaén, fue nombrado en 534/1139-1140 después de Abū 1-Faḍl 'Iyāọ b. Mūsà. Ejerció este cargo hasta su muerte.

15. Abū 1-'Abbās Aḥmad b. 'Abd al-Raḥmān b. Muḥammad b. 'Abd al-Rahmmān b. Muḥammad, Ibn al-Ṣaqr al-Anșārī al-Jazraŷī 29 (m. 569/1173). Natural de Granada. Secretario del cadí Abū 'Abd Allāh b. Hassūn b. al-Bazzāz cuando éste era cadí de Marrakech en 527/1132-1133. Cuando nombraron a 'Iyāẹ cadí de Granada, lo nombró secretario suyo hasta que Tāšufīn lo destituyó en 534/ 1139-1140. El sucesor de 'Iyāẹ, Abū 'Abd Allāh b. 'Alī al-Azdī al-Ŷayyānī b. al-Hāŷŷy al-Afțas, nombró a Abū l-'Abbās al-Jazraŷi para los aḥkām wa-l-sālāt en Guadix. Ejerció este cargo hasta la muerte del citado Abū 'Abd Allāh en 536/1141-1142 y luego regresó a Granada. Dice Ibn al-Zubayr que fue nombrado cadí de Granada. Ibn 'Abd al-Malik informa de que fue cadí, pero por poco tiempo y que posiblemente ocupaba este cargo por delegación. Dimitió a finales de la época almorávide, pero su renuncia no fue aceptada. En la época almohade, ejerció el cargo de los aḥām ${ }^{30}$ de Marrakech; luego fue cadí de Gra-

1402/1982, 101; Ibn al-Zubayr, Silat al-șila, ed. Lévi-Provençal, 425; Ibn al-Qādīi, $\hat{Y} a d w a$, II/568, 498-499; Ibn Farhūn, al-Dībāŷy, II/46-51; Ibn al-Jatīb, al-Ihāta fì ajbār Garnāta IV/222; Ibn 'Askar, A ' làm Màlaqa, 81, 331. Hasan al-Warāglī ha publicado un estudio bibliográfico sobre 'Iyād, titulado Abū l-Fậdl al-qāḍ̄ 'Iyād al-Sabtī, tabat biblyūŷrāfì, Beirut, 1994; Šaqūr, A. S., al-Qāḍ̂ 'Iyād al-adīb (al-adab al-magribī fì zill al-murābițīn), Tánger, 1983. También véanse Hermosilla Llisterri, M. José, "Las obras andalusíes en la Gunya del qāọi 'Iyāḍ’", Anuario de Filología V (1979), 185-202; Bencherifa, M., "Wațā'iq andalusiyya fĩ nawāzil al-qāḍī 'Iyāḍ", Da 'wat al-Haqq 264 (1987), 29-35; al-Tāzī, ‘A. H., “'Iyāọ fī Fās”, Awrāq IV (1981), 165-172. Véase también Serrano, D., "Los Banū 'Iyād".

${ }^{28}$ Ibn al-Abbār, al-Takmila, ed. El Cairo, 1257.

29 Al-Marrākušì, al-Dayl, I. ed. Bencherifa, 292; Ibn Farhūn, al-Dībāŷy, I/211-214; Ibn al-Abbār, al-Takmila, ed. El Cairo, 201.

30 Sobre los ahkām, véase El Hour, R., "Le sāhib al-ahkām à l'époque almoravide", Al-Andalus-Magreb 8-9 (2000-2001), 49-64 y Müller, C., "Administrative tradition and 
nada, y de Sevilla. En la época de Abū Ya'qūb al-Manșūr se encargó de la juțtat al-jizāna al- 'äliya (tesorería).

16. Abū Muḥammad 'Abd Allāh b. Aḥmad b. Simāk ${ }^{31}$, al-"Āmilī ${ }^{32}$ (m. 540/1145). Natural de Granada. Fue jurisconsulto y cadí de Granada en 537/1142-1143. Permaneció en su cargo hasta 540/1145-1146.

17. Abū Jālid y Abū Muhammad 'Abd Allāh b. Muhammad b. 'Abd al-Raḥmān b. Muḥammad b. Muhammad b. 'Abd Allāh b. Zamanīn al-Murrī (m. 545/1150) ${ }^{33}$. Natural de Granada. Jurisconsulto y cadí, debió de ocupar el cargo entre 540/1145 y 541/1148, ya que las fechas referentes al resto de los nombramientos están mejor documentadas. En todo caso, hay que tener en cuenta la situación de desorden generada por las revueltas que estallaron en todo el territorio andalusí a partir de 539/1145. No cabe duda de que dichas revueltas afectaron en gran medida a Granada como capital andalusí que era.

18. Abū 1-Hasan y Abū Yahyà Hāni' b. 'Abd al-Rahmān b. Hāni’ al-Lajmī, al-Bazīzī. Fue cadí de Granada en 541/1146-1147.

19. Al-Hasan b. 'Abd al-Raḥmān b. al-Hasan b. Qāsim b. Mušarrif b. Qāsim b. Hāni' al-Lajmī, Abū 'Alī. Yaḥyà b. Gāniya lo nombró cadí de Granada desde 542/1147-1148 hasta finales de ŷumādà de 551/mediados de agosto de 1156, casi 9 años.

Después de este recorrido por las fuentes biográficas sobre los cadíes de Garanada, voy a pasar a analizar la política que aplicaron los almorávides en el cadiazgo de Granada.

civil jurisdiction of the Cordoban șāhīb al-aḥkām (I) y (II)", Al-Qanțara XXI (2000), 57-84 y 307-338.

31 Véase Bosch Vilá, J., "Los Banū Simāk de Málaga y Granada, una familia de cadíes", MEAH XI (1962), 21-37.

${ }^{32}$ Ibn al-Abbār, al-Takmila, ed. El Cairo, p. 827 (n. ${ }^{\circ}$ 2012); Ibn al-Zubayr, Șilat al-șila, ed. 'A. Harrās y S. A'rāb, 156; Ibn al-Jațīb, al-Ihāṭa, III/410; Ahmad Bābā, Nayl

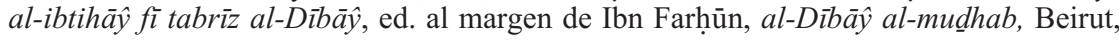
[s.a] 132.

${ }^{33}$ Ibn al-Zubayr, Ṣilat al-ṣila, ed. 'A. Harrās y S. A'rāb, 162; Ibn Farḥūn, al-Dībāây, I, p. 446; Ibn al-Jațīb, al-Ihạțta, t. III/412-413; Ibn al-Abbār, al-Takmila, ed. El Cairo, 829 (n. $\left.{ }^{\circ} 2016\right)$.

Al-Qanțara (AQ) XXVII 1, enero-junio 2006, pp. 5-23 ISSN 0211-3589 


\section{Cadiazgo y poder político}

Lo que hemos visto sobre la procedencia social y geográfica del cadiazgo de Granada puede ayudarnos a aclarar algunos aspectos relacionados con la política judicial almorávide, dada la elección de la ciudad de Granada en el período almorávide como capital andalusí. Dicha elección se debió, en mi opinión, a razones estrictamente político-militares. Pero ¿afectó esto a la política de los nombramientos de los cargos judiciales? Dicho de otra manera, ¿influyó la elección de Granada como capital en la relación entre el poder político y el socio-judicial? Quizás este aspecto se aclararía con el estudio de los componentes del cadiazgo de la ciudad.

En mi opinión, los primeros signos de la política almorávide en Granada se aprecian ya en su primera decisión judicial una vez consolidado su poder en Granada: destitución del cadí Abū l-Aṣbag b. Sahl. Ya he señalado que las fuentes relacionan dicha destitución con la dureza del cadí en sus sentencias, pero los verdaderos motivos estaban probablemente relacionados con la nueva política que quisieron aplicar los almorávides en al-Ándalus, sobre todo la de trazar una nueva línea en su relación con el poder local andalusí. Ibn Sahl había desempeñado varios cargos en la administración de justicia tanto andalusí como norteafricana (bargawātí) y nunca se habían cuestionado, que se sepa, sus sentencias. Por otro lado, la adaptación u oportunismo demostrado por Ibn Sahl por su ejercicio del cadiazgo de diversas ciudades del Occidente islámico al margen del régimen que gobernaba, sobre todo en el caso de los bargawātíes, posiblemente hizo que los almorávides sospecharan de su lealtad hacia ellos.

El caso de Granada es muy singular por lo que respecta a la procedencia de los cadíes, sobre todo si lo comparamos con el de otras ciudades andalusíes de la importancia de Granada, como pueden ser Córdoba ${ }^{34}$, Sevilla ${ }^{35}$ y Valencia ${ }^{36}$.

34 Todos los cadíes eran de Córdoba. Véase El Hour, R., "Córdoba frente a los almorávides: familias de cadíes y poder local en al-Andalus", RIEEI XXIX (1997), 182-210.

35 Sus cadíes en su mayoría eran sevillanos, con la presencia de un magrebí. Véase El Hour, R., "Sevilla en época almorávide: sede de una importante administración judicial", RIEEI XXXI (1999), 33-50.

36 Tanto en Valencia como en el resto de las localidades del Levante, los cadíes eran de la zona. La única excepción fue el nombramiento del cadí magrebí Abū Muhammad al-Waŷdī. Véase El Hour, R., "El Levante de al-Andalus: jueces y élites locales", Al-Andalus-Magreb X (2003), 53-89.

Al-Qanțara (AQ) XXVII 1, enero-junio 2006, pp. 5-23 ISSN 0211-3589 
Tal como he mencionado en otra ocasión ${ }^{37}$, los almorávides pactaron el reparto de poderes con el poder local andalusí, teniendo en cuenta el papel que desempeñarían tanto las familias como las figuras magrebíes que se trasladaron a al-Ándalus con los almorávides; tal es el caso de los Banū Samaŷūn. Como se puede ver a continuación, el cadiazgo de Granada es un buen ejemplo a este respecto.

Tras la destitución de Ibn Sahl en 485/1092-3 o 486/1093-4, la máxima autoridad político-religiosa almorávide, el emir, efectuó el primer nombramiento de cadíes en la ciudad. La elección recayó en un andalusí, Ibn Sayyid Abī-hi. Lo primero que hay tener en cuenta es que nuestro personaje no era granadino; y tampoco magrebí - hubiera supuesto asumir un gran riesgo en vista de su futura relación con el poder local andalusí - por lo que es posible que los almorávides quisieran proporcionar un nuevo estatuto político-jurídico a la ciudad de Granada. Recuérdese que era la capital, con todo lo que esto conlleva de importancia política, burocrática e incluso militar para los nuevos amos de al-Ándalus. Otro hecho de gran importancia política ocurriría poco años después. El gobernador de Granada, Yahyà, desterró o expulsó a Ibn Sayyid Abī-hi (az'âya-hu 'an-hā) de Granada a Córdoba en 489/1096-7. Aquí no se habla de ninguna destitución, sino de un destierro (nafy o iz'ây), por lo que se ve que el cadí debió de cometer un «grave error», una traición por ejemplo, en lo que a su relación con el poder político se refiere, o simplemente se trata de un intento de confirmación del poder almorávide en la ciudad. Es posible que nuestro personaje rompiera las reglas del juego político «pactadas» con el poder local andalusí. No se puede descartar la posibilidad de que el poder local granadino estuviera detrás de este problema. Al fin y al cabo, el objetivo principal sería recuperar el poder sobre la ciudad por parte de los granadinos, y evitar que esto sucediera por parte de los almorávides.

Cabe la posibilidad de que el poder político buscara pretextos para justificar el nombramiento de un cadí no andalusí, hecho que se producirá inmediatamente tras el destierro de Ibn Sayyid Abì-hi. Se trata de Abū Muhammad b. Samaŷūn ${ }^{38}$. Fue el primer nombramiento de

37 Véanse mis artículos: "The Andalusian qādī in the Almoravid period: political and judicial Authority”, Sudia Islamica 90 (2000), 67-83; «Biografías de cadíes en época almorávide: análisis de las fuentes árabes» en M.L. Ávila- M. Marín (eds.), EOBA VIII (1997), 177-199.

38 No vamos a hablar de esta familia magrebí, pues ya existe un trabajo monográfico

Al-Qanțara (AQ) XXVII 1, enero-junio 2006, pp. 5-23 ISSN 0211-3589 
un magrebí hecho por los almorávides en tierras andalusíes. Y creo que esta designación fomaba parte de un plan político-judicial para debilitar la posible resistencia del poder local de al-Ándalus, el granadino en este caso. En esta última ciudad, el nombramiento de magrebíes se multiplicaba y se observaba que el poder local granadino perdía progresivamente el control de los cargos claves de su supervivencia política.

El poder local granadino no tardó mucho en manifestar su descontento ante la política aplicada por los almorávides en la ciudad, especialmente la que marcaba las bases sobre las que debía asentarse la relación entre el poder político y judicial. El nombramiento de Ibn Samaŷūn posiblemente fue la gota que colmó el vaso. Ibn Samaŷūn fue destituido a causa del conflicto que mantuvo con los alfaquíes de Granada, siendo sustituido por Abū Bakr al-Qulay`ī, «a quien la gente de Granada pidió que ocupara el cadiazgo» ${ }^{39}$. Como consecuencia de este conflicto, Abū Bakr Gālib b. 'Ațiyya, uno de los personajes más importantes de la ciudad, fue deportado al Sūs y el emir de Córdoba Mazdalī humilló y menospreció a 'Abd al-Haqq (hijo de Gālib b. 'Ațiyya) y lo encarceló ${ }^{40}$. Según Ibn 'Ayyād, fue deportado junto a su padre.

Este hecho puede confirmar, entre otras cosas, el rechazo andalusí a los cadíes procedentes del Magrib, a Ibn Samaŷūn en este caso, aunque algunos estudiosos dejan la puerta abierta ante la posiblidad de que el conflicto tuviera otras causas relacionadas con el conocimiento y el pensamiento teológico de Ibn 'Ațiyya ${ }^{41}$. En mi opinión, el conflicto se debió más bien a razones políticas y otras sociales relacionadas con el espacio vital del poder local granadino y su monopolio sobre los cargos judiciales y la vida social de la ciudad de Granada. No hay que olvidar que los Banū Samaŷūn era una de las familias que entraron en al-Ándalus con la llegada de los almorávides.

al respecto. Véase Lucini, M., "Los Banū Samaŷūn: una familia de cadíes”, EOBA V (1992), 171-198.

39 Ibn al-Abbār, al-Takmila, ed. al-Husaynī, I, 1166.

40 Véase también Serrano, D., "Los almorávides y la teología aš‘arí: ¿Contestación o legitimación de una disciplina marginal?", en C. de la Puente (ed.), Identidades marginales. EOBA XIII (2003), 461-516, 494-5.

${ }^{41}$ Serrano, D., op. cit., 479 y 494-5. La autora apunta que "Su padre - Gālib b. "Atiyya - aparece, junto con Ibn al-Bādiš, entre los maestros de un personaje que sabía kaläm”.

Al-Qanțara (AQ) XXVII 1, enero-junio 2006, pp. 5-23 ISSN 0211-3589 
Aunque los almorávides eran conscientes de las consecuencias que tendría el nombramiento de cadíes no sólo no-andalusíes, sino también de cadíes andalusíes procedentes de otras ciudades distintas de Granada, dado el poder social y económico de las familias granadinas ${ }^{42}$, reiteraron su política de nombramientos al designar en el cadiazgo de la ciudad, como se ha podido apreciar, a jueces procedentes de la otra orilla del Mediterráneo. En mi opinión, la única explicación a esta persistencia/desafío de las autoridades políticas reside en el hecho de que Granada había sido elegida capital de al-Ándalus, y no querían bajo ningún concepto correr el riesgo de dejar el control de la administración de justicia en manos de unas familias granadinas que pudiesen amenazar su existencia. La política judicial almorávide en Granada encuentra su justificación en sus temores político-militares, porque en el caso contrario ¿cómo explicaríamos la no designación de jueces magrebíes en el cadiazgo de ciudades como Córdoba, aun siendo conscientes de la importancia intelectual y religiosa tanto de la ciudad como de su poder local? ${ }^{43}$. Quizás el empeño almorávide para conseguir el control político-militar de al-Ándalus hizo que determinados sectores entre las élites andalusíes se sintieran marginados, lo que llevó a cambios que no tardarían mucho en producirse, adelantando la salida almorávide de al-Ándalus.

Los almorávides practicaron una política cambiante que responde a la necesidad de mantener el equilibrio entre sus intereses y los de las élites locales de las que tampoco podían prescindir. Pues tras la destitución de Ibn Samaŷūn, los almorávides recurren a un miembro de una familia andalusí y granadina, que destacó en época almorávide. La familia de los Banū al-Qulay 'ī había manifestado su lealtad a los almorávides desde su llegada a al-Ándalus. Los Banū 1-Qulay'ī eran representados por Abū Bakr b. al-Qulay'ī, hijo de Abū Ŷa'far, que tomó parte activa en la caída de Granada en manos almorávides. Respecto a esta familia, las fuentes manejadas no ofrecen ningún dato acerca de sus an-

\footnotetext{
42 A pesar de que los almorávides eran conscientes de la reacción del poder local granadino, al verse éste cada vez más alejado de las funciones judiciales, no hicieron nada para impedir el posible enfrentamiento con él. La actitud de las autoridades almorávides hace pensar que estas últimas deseaban este choque, ya que les proporcionaba los pretextos para deshacerse del poder de las familias locales. El caso de los Banū 'Ațiyya es un claro ejemplo de ello.

43 Véase la composición del cadiazgo de esta ciudad en El Hour, R., "Córdoba frente a los almorávides".
}

Al-Qanțara (AQ) XXVII 1, enero-junio 2006, pp. 5-23 ISSN 0211-3589 
cestros, ni sobre sus descendientes directos, en los cuales se incluye el padre de Abū Ŷa'far. El nombre completo de este último puede proporcionarnos la información de que el padre llevaba el nombre de Jalaf b. 'Abd al-Malik al-Gassānī al-Qulay'ī, y posiblemente su laqab era Abū 1-Qāsim. Basándonos en el mismo procedimiento, el abuelo de Abū Ŷa'far se llamaría 'Abd al-Malik al-Gassānī al-Qulay'ī, y posiblemente su laqab era Abū Marwān, por lo que se podría llegar a deducir que 'Abd al-Malik fue el fundador de la familia al-Qulay'ī. No se sabe mucho de su familia, de lo cual podría llegarse a la conclusión de que la familia sólo empieza a ser importante con Abū Ŷa far. Gracias a este último, la familia cobró una gran importancia en época de taifas y muy particularmente en época del emir 'Abd Allāh b. Bulluggīn, que le nombró visir y hombre de confianza ${ }^{44}$.

Después de al-Qulay'ī, de nuevo tenemos a un magrebí en el cadiazgo de la ciudad. Se trata de Ibn Jalaf Allāh al-Ṣanhāŷī, que inicia una serie de magrebíes - hasta un total de cinco - pertenecientes a grandes familias en el cadiazgo de Granada: 'Iyāọ, Ibn Samaŷūn y al-Șanhâŷ̀i. Granada fue la única ciudad con tanta presencia magrebí en su cadiazgo. Es verdad que el cadiazgo de la ciudad de Algeciras estaba monopolizado por magistrados magrebíes, pero ha de tenerse en cuenta que el estatuto de esta ciudad era el de cualquier ciudad magrebí, dado el hecho de que los almorávides la habían recibido por parte de los andalusíes (al-Mu'tamid de Sevilla) a cambio de su intervención en al-Ándalus.

Por otro lado, es muy importante señalar que los almorávides, en cambio, efectuaron diversos nombramientos de cadíes de origen andalusí para ejercer sus cargos en el Magrib. Se tienen noticias por ejemplo de Abū Muḥammad 'Abd Allāh b. Ismā'îl ${ }^{45}$, que era natural de Sevilla. Fue cadí de Agmāt; luego fue cadí de la Hadra (Marrakech), donde permaneció hasta que murió en 497/1103-1104. Por su parte, Abū l-Qāsim Jalaf b. 'Umar b. Jalaf b. Sa'd b. Ayyūb b. Wārit al-Tuŷībī ${ }^{46}$ fue cadí de Agmāt. Lo único que sabemos de él es que residió en Zaragoza y que ejerció su cargo hasta que murió poco des-

44 Véase Ibn al-Jațīb, al-Ihāṭa, I, 147-50; Fihris Ibn 'Ațiyya, 96-7; Ibn Baškuwāl, $\mathrm{n}^{\circ} 157,75$.

45 Ibn Baškuwāl, Sila, ed. El Cairo, 636; Ibn al-Zubayr, Șilat al-șila, ed. 'A. Harrās y S. A'rāb, 134

46 Ibn al-Abbār, al-Takmila, ed. El Cairo, 819.

Al-Qanțara (AQ) XXVII 1, enero-junio 2006, pp. 5-23 ISSN 0211-3589 
pués de 500/1106-1107. 'Īsà b. Fatḥ ${ }^{47}$, residente en Játiva, fue cadí de Agmāt por un período de tres años. Murió en 504/1110-1111. Abū Muhammad 'Abd Allāh b. 'Alī al-Lajmī, Sibṭ Abī 'Umar b. 'Abd al-Barr ${ }^{48}$, que era natural de Játiva, fue nombrado cadí de Agmāt hasta que murió en 533/1138-1139.

No cabe duda que el cargo de cadí de Agmāt fue un gran privilegio en esta época, ya que, como se sabe, Agmāt era una de las ciudades más importantes del Magrib, a nivel económico y cultural, y un centro comercial muy destacado. Agmāt gozó de una gran importancia, en particular antes de la fundación de la ciudad de Marrakech, que se benefició de la nueva política almorávide a lo largo de la primera mitad del siglo VI/XII ${ }^{49}$. La ciudad de Ceuta también fue destino de los nombramientos de cadíes andalusíes en el Magrib, entre los que se pueden mencionar a Abū 'Abd Allāh b. 'Abd al-Barr b. Zarqūn al-Anșārī ${ }^{50}$, que era natural de Jerez de la Frontera y que fue nombrado cadí de Ceuta después de haber sido secretario de 'Iyāạ. Abū Hafṣ 'Umar b. 'Abd al-Raḥmān b. 'Abd al-'Azīz b. 'Umar b. Husayn b. 'Uḍra al-Anșārī ${ }^{51}$, natural de Algeciras, fue nombrado cadí de Ceuta y Algeciras.

A través de la lista de estos cadíes andalusíes que ejercieron sus cargos en el Magrib en época almorávide, se observa que algunos de ellos posiblemente pertenecían a familias andalusíes conocidas en épocas anteriores, como es el caso de la familia al-Tuŷībī. Es probable que fuera un miembro de la misma familia que gobernó en Zaragoza antes de ser ocupada por los Banū Hūd en el trascurso del s. V/XI. Además vemos que hay un miembro de la familia al-Lajmī, nieto de Abū 'Umar b. 'Abd al-Barr ${ }^{52}$.

47 Al-Marrākušǐ, al-Dayl, V/2, ed. I. 'Abbās, 927.

48 Ibn al-Abbār, al-Takmila, ed. El Cairo, p. 821 (n. $\left.{ }^{\circ} 2002\right)$.

49 Véase Daroua, M., Les oulamas andalous au Maroc aux époques almoravide et almohade, Tesis de Tercer ciclo, Universidad de París I, Pantheon-Sorbonne, 1987, pp. 127-128.

50 Al-Marrākušì, al-Dayl, VI, 597; Ibn al-Abbār, al-Takmila, ed. El Cairo, p. 540 (n. ${ }^{\circ}$ 1468); Ibn Farhūn, al-Dībā̂y, II/259-260.

51 Ibn al-Zubayr, Șilat al-șila, ed. Lévi-Proveçal, 120; Ibn al-Abbār, al-Takmila, ed. Codera, 1826; al- Marrākušì, al-Dayl, V/2, 773.

52 Véase Fierro, M., "Ibn 'Abd al-Barr, Abū 'Umar” en Enciclopedia de al-Andalus. Diccionario de Autores y Obras Andalusies, Granada: Fundación Legado Andalusí, 2002, I, 287-92, espec. 289.

Al-Qanțara (AQ) XXVII 1, enero-junio 2006, pp. 5-23 ISSN 0211-3589 
Me llama la atención que ningún miembro de las familias andalusíes «especializadas» en funciones judiciales en época almorávide, como los Banū Hamdīn, los Banū Rušd, los Banū al-Aṣbag de Córdoba o los Banū Ýaḥhāf de Valencia, entre otras, fuese nombrado cadí en Magrib. Estas familias gozaban de gran prestigio por su nasab y por su peso político-económico. En cambio, miembros de familias que carecieran de «protección» familiar eran mucho más manejables por la administración almorávide.

Volvamos a cadiazgo de Granada. Se puede observar que junto con los jueces procedentes u originarios del Magrib, hubo otros andalusíes, pero no todos granadinos. Tenemos miembros de diversas familias andalusíes: Banū Hāni' de Granada, Banū Ward de Almería, Banū Abī Ŷamra de Murcia, Banū Hassūn al-Kalbī y Banū Simāk al-`Āmilī de Granada y Málaga. ¿Qué pretendían los almorávides con estos nombramientos?

Se puede apreciar que los almorávides, además de alternar entre familias magrebíes y andalusíes, granadinas y no granadinas para gestionar el cadiazgo de la ciudad, tendieron a no dejar el cadiazgo en manos de familias granadinas, hecho que rara vez se vio en otras localidades andalusíes tan importantes como Granada, al menos hasta la desestabilización de la situación en al-Ándalus a finales de los años treinta del siglo XII. No hay que olvidar, por otro lado, que el nombramiento de cadíes que pertenecían a familias andalusíes no granadinas es a su vez un hecho políticamente muy significativo, ya que observamos que estos cadíes ejercen sus cargos fuera de sus propias localidades, como es el caso de Abū 1-Qāsim b. Ward, que desempeñó sus funciones en varios lugares, excepto en su ciudad, Almería ${ }^{53}$. Sin embargo, ha de tenerse en cuenta que Ibn Gāniya, último gobernador almorávide en Granada, ofreció el cadiazgo de la ciudad a la familia de los Banū Hāni' hasta la caída de la ciudad en manos almohades ya en 551/mediados de agosto de 1156. Los Banū Hāni' controlaron el cadiazgo durante un período de 10 años, desde 541/1147-8 hasta $551 / 1156$. Por lo que se ve, la debilidad almorávide propició que la familia de los Banu Hāni' monopolizara el cadiazgo de la ciudad, y fue la primera vez que dos miembros de la misma familia se sucedían en el cadiazgo de Granada durante esta época. Recuérdese que un

\footnotetext{
53 Véase El Hour, R., "Almería almorávide: sede de una oposición política y de un importante poder judicial".
}

Al-Qanțara (AQ) XXVII 1, enero-junio 2006, pp. 5-23 ISSN 0211-3589 
miembro de esta misma familia había ocupado el cargo de cadí con anterioridad. Se trata de Abū Bakr 'Abd al-Raḥmān b. Hāni', antes mencionado, que debió de ocupar el cadiazgo de Granada entre 524/1130 ó 525/1131 y 529/1134-5.

Ha de tenerse en cuenta que la ciudad de Granada no cayó en manos almohades hasta 551/1156-1157 y que en 556/1161-1162 pasó a ser controlada por Ibn Hamušk ${ }^{54}$. Pero ésta es otra época que aquí no vamos a tratar.

No hay dato alguno acerca de la situación judicial de la ciudad en el período en el que Granada estaba en manos de Ibn Aḍà. Sin embargo, se pueden establecer algunas hipótesis. Se sabe que Ibn Aḍà se proclamó $r a$ 'īs de la ciudad y que reconoció a Ibn Hamdīn en ramaḍān de 539/marzo de $1145^{55}$, según la versión de Ibn al-Abbār ${ }^{56}$ : qāma bi-da'wat Ibn Hamdin. A partir de ello, creo posible que Ibn Aḍ̣à haya conservado a Ibn Simāk al- 'Âmilī en su cargo de cadí ${ }^{57}$ hasta que murió en ramaḍān de 540/marzo de 1146; es decir, que Ibn Simāk siguió en su cargo durante el año de la fitna en la ciudad (ramaḍān de 539/marzo de 1145 hasta ramaḍān de 540/marzo de 1147). Esto, a su vez, puede conducir a la conclusión de que Ibn Simāk, o bien conspiró contra los almorávides, o bien toleró la revuelta por haber aceptado ejercer el cargo bajo el mandato de Ibn Aḍhà. Por otra parte, Ibn Hamdīn, tal y como había hecho con Ibn Abì Ŷa'far de Murcia, pudo haber nombrado a Ibn Aḍhà en el cadiazgo de Granada, al menos hasta que entró Ibn Hūd en la ciudad, y con ello, cabe la posibilidad de que Ibn Aḍhà haya destituido a Ibn Simāk. Además Ibn 'Abd al-Malik al-Marrākušī ${ }^{58}$ informa de que los granadinos, ante su incapacidad de hacerse con la Alcazaba, en la que se habían refugiado los almorávides, se pusieron de acuerdo para nombrar a un ra'īs y ofrecerle el mando. Ibn Aḍhà y algunos alfaquíes de la ciudad votaron a favor de Ibn Hamdīn de Córdoba, mientras que la mayoría estaba a favor de llamar a Ibn Hūd. Frente a esta situación, Ibn Aḍ̣à y

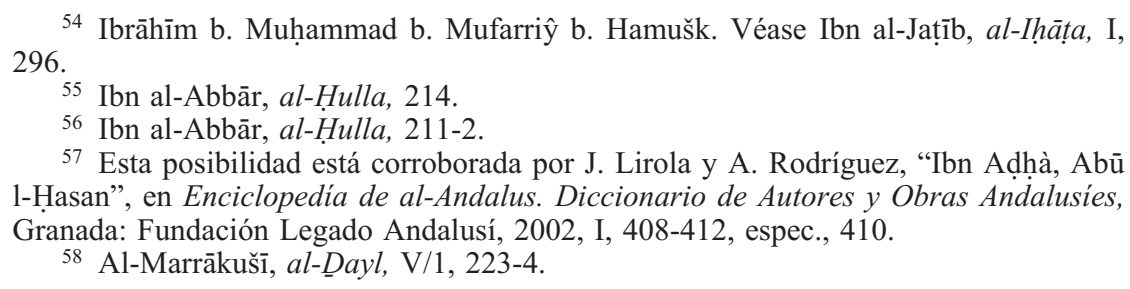

57 Esta posibilidad está corroborada por J. Lirola y A. Rodríguez, "Ibn Adhà, Abū 1-Hasan”, en Enciclopedía de al-Andalus. Diccionario de Autores y Obras Andalusies, Granada: Fundación Legado Andalusí, 2002, I, 408-412, espec., 410.

58 Al-Marrākušī, al-Dayl, V/1, 223-4. 
sus seguidores se incorporaron al segundo grupo y se pusieron todos de acuerdo en llamar a Ibn Hūd. Y para ello enviaron a dos alfaquíes: Abū 1-Ḥasan Ibn Aḍ̣à y el jurisconsulto Abū Ŷa'far b. Țalha b. 'Atịya 59 .

Según lo señalado, se puede ver que los alfaquíes de la ciudad de Granada encabezaron la revuelta e incluso la embajada que pidió ayuda a Ibn Hūd. Ibn 'Abd al-Malik pone de relieve el papel de dos familias destacadas de Granada, la de los Banū Aḍhà ${ }^{60}$ y una rama de la de los Banū 'Ațiyya.

\section{Conclusiones}

La importancia política y militar de Granada (capital de al-Ándalus), hizo que las autoridades político-militares almorávides no negociaran con las familias granadinas en lo que al cadiazgo de la ciudad se refiere. Ello apunta también a un poder político y militar que se considera lo suficientemente fuerte como para prescindir de las élites locales. Es verdad que el cadiazgo de Granada fue gestionado por varias familias andalusíes, granadinas y no granadinas, y no por voluntad propia de los granadinos, sino por imposición de las autoridades almorávides, pero también - no incluyo a Algeciras por razones ya señaladas y ligadas especialmente al estatuto de la ciudad - se aprecia la presencia de varias figuras e incluso familias magrebíes en el cadiazgo de la ciudad. En ciudades como Valencia, Almería, Sevilla, Córdoba, Málaga, se puede apreciar el monopolio del poder local sobre el cadiazgo, con una presencia mínima de figuras magrebíes, tal como fue el caso de Valencia (Abū Muhammad al-Waŷdī) y Almería, Sevilla (Ibn Samaŷūn). También se puede destacar un dato de gran importancia. Los almorávides se conformaron con la designación de determinadas figuras en el cadiazgo de diversas localidades andalusíes, pero en el caso de Granada, además de nombrar a personajes muy destacados, como Jallūf e Ibn Ḥammād al-Ṣanhāŷì, hicieron que destacara una familia magrebí, los Banū Samaŷūn, no sólo en el ca-

59 Al-Marrākušī (al-Dayl, V/1, 224) informa que Ibn Aḍhà e Ibn 'Ațiyya murieron durante el enfrentamiento con los almorávides.

${ }^{60}$ Familia andalusí muy famosa (min al-bayt al-šahīr bi l-Andalus). Véase lo que dice dice al-Bunnāhī (p. 124) de uno de los descendientes de Abū l-Ḥasan b. Aḍhà.

Al-Qanțara (AQ) XXVII 1, enero-junio 2006, pp. 5-23 ISSN 0211-3589 
diazgo de Granada, sino también de otras ciudades como Almería y Sevilla.

No cabe duda de que los almorávides ejercieron un control estricto sobre la ciudad, sus habitantes y sus instituciones. Sin embargo, ha de señalarse que los granadinos, excepto algunas familias leales a los almorávides, como es el caso de los Banū al-Qulay ‘̄î, no desaprovecharon ninguna oportunidad para manifestar su oposición, desacuerdo y malestar con la política judicial almorávide, tal como he indicado anteriormente al hablar del conflicto entre los Banū Samaŷūn y los Banū 'Ațiyya (la repuesta de las autoridades políticas fue contundente), el levantamiento de Ibn Adhà y la implicación de varias familias granadinas en el complot contra los almorávides, aunque el control de la ciudad fue recuperado en 540/1146. Los hechos protagonizados por Ibn Aḍhà pusieron en evidencia su desleatad y la de algunas familias, y la lealtad de otras, como los Banū Hāni' al-Lajmī. Creo que la mayor parte de los «traidores» fueron ejecutados por los almorávides, aunque algunos, como los Banū Simāk al-'Âmilī, supieron aprovecharse de la situación para ganarse a los nuevos amos de al-Ándalus, los almohades. Abū 'Abd Allāh Muḥammad b. 'Abd Allāh b. Ahmad b. Simāk al-'Āmilī fue el primer cadí nombrado por los almohades para el cadiazgo de Málaga y luego de Granada tras su caída en $551 / 1156$.

\section{Fuentes árabes}

AḤmad BĀBĀ, Nayl al-ibtihāŷy fì tațīz al-Dībāŷ, ed. al margen de Ibn Farḥūn, al-Dībāŷy al-mudhab, Beirut, [s.a].

AL-BunNĀHĪ, al-Marqaba al- 'ulyā, ed. E. Lévi-Provençal, El Cairo, 1948.

AL-DABBī̄, Bugyat al-multamis fì ta'rīj rî̀âl al-Andalus, ed. Ibrāhīm al-Abyārī, Beirut, 1989. 2 vols.

IBN AL-ABBĀR, al-Takmila li-kitāb al-Șila, ed. F. Codera, Madrid, 1887-89, 2 vols.

- al-Takmila li-kitāb al-Sila, ed. 'I. al-Ḥusaynī, El Cairo, 1955, 2 vols.

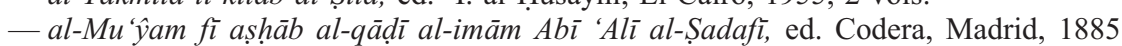
(B.A.H., IV).

- al-Hulla al-siyarā', ed. H. Mu'nis, El Cairo, 1963, 2 vols.

IBN 'ÁSKAR, A 'lām Mālaqa, ed. 'A. al-Murābit al-Targī, Beirut-Rabat: Dār al-Garb al-Islāmī-Dār al-Amān, 1999.

IBN 'AṬıYYA, 'Abd al-Ḥaqq al-Muhāribī, Fihris Ibn 'Atịyya, ed. M. al-Zāhī y M. Abū al-Aŷ́fān, Beirut, 1980.

IBN BAŠKUWĀL, Jalaf b. 'Abd al-Malik, Kitāb al-Ṣila, ed. 'I. al-'Atțār, El Cairo, 1955.

IBN FARHūN, Ibrāhīm b. 'Alī, al-Dībāŷy al-mudhab fì ma 'rifat a 'yān 'ulamā' al-madhab, El Cairo, 1972, 2 vols.

Al-Qanțara (AQ) XXVII 1, enero-junio 2006, pp. 5-23 ISSN 0211-3589 
IBN 'IDQ̄ễI, al-Marrākušī, al-Bayān al-mugrib fĩ ajbār al-Andalus wa-l-Magrib, vol. IV, ed. I. 'Abbās, Beirut, 1967. Trad. A. Huici Miranda, al-Bayān al-mugrib fí-jtișār ajbār mulūk al-Andalus wa-l-Magrib, Tetuán, 1953, 2 vols.

IBN JĀQĀN, Qalā'id al- 'iqyān fì mahāasin al-a 'yān, ed. Sulaymān al-Ḥarā'irī, [s.a]; y la edición fotocopiada de la edición de París, Túnez, 1966.

IBN AL-JAṬīB, al-Iḥătạ fì ajbār Garnāṭa, ed. M. ‘A 'Inān, El Cairo, 1975 y 1977 (4 vols.).

IBN AL-QĀḌI, Ŷadwat al-iqtibās fì dikr man halla min al-a lām madinnat Fās, Rabat, 1973-74, 2 vols.

IBN SA‘ī, al-Mugrib fì hulà al-Magrib, ed. Š. Dayf, El Cairo, 1955.

IBN AL-ZUBAYR, Șilat al-ṣila, ed. 'A.S. al-Harrās y S. A'rāb, Al-Muhammadiyya, 1993.

IBN AL-ZUBAYR, Șilat al-șila, ed. E. Lévi-Provençal, Rabat, 1937.

'IYĀD, Tartīb al-madārik wa-taqrīb al-masālik li-ma'rifat a 'lām mad̂hab Mālik, varios editores, Rabat, s. a., 1983, 8 vols.

MAJLūF, M., Šaŷarat al-nūr al-zakiyya fì tabaqāt al-mālikiyya, El Cairo, 1950-52.

AL-MARRĀKUŠĩ, Ibn 'Abd al-Malik, al-Dֵayl wa-l-takmila, IV (2), ed. I. 'Abbās, Beirut, s. a.

— al-Dayl wa-l-takmila, VI, ed. I. 'Abbās, Beirut, 1973.

- al-Dayl wa-l-takmila, t. V/2, ed. I. 'Abbās, Beirut, 1965.

AL-MARRĀKUŠİ, Ibn 'Abd al-Malik, al-Ḍayl wa-l-takmila, VIII, ed. M. Bencherifa, Rabat, 1984, 2 vols.

Al-SiLAFĪ, Ajbār wa-tarāŷim andalusiyya, ed. I. 'Abbās, Beirut, 1963. 